\title{
Sample Viability Percent Measurement
}

National Cancer Institute

\section{Source}

National Cancer Institute. Sample Viability Percent Measurement. NCI Thesaurus. Code C139278.

A measurement of the percent of a cell or tissue sample that is viable. 